\title{
SELF-DETERMINATION AND FOREIGN DIRECT INVESTMENT: REIMAGINING SOVEREIGNTY IN INTERNATIONAL INVESTMENT LAW
}

\author{
EDWARD GUNTRIP*
}

\begin{abstract}
International investment law can be criticized for its understanding of sovereignty. Informed by the works of Koskenniemi, this article reimagines 'sovereignty' based on a host State population exercising its right to economic self-determination. Recent transparency initiatives in international investment law support this conceptualization of sovereignty. Further, the stance taken aligns with the continuous evolution of the international investment law regime. The establishment of a different perspective on sovereignty in international investment law highlights the need for an alternative understanding of this term if international investment law is to achieve widespread approval.
\end{abstract}

Keywords: economic self-determination, international investment agreements, international investment law, Koskenniemi, sovereignty.

\section{INTRODUCTION}

International investment law (IIL) can be criticized for its understanding of sovereignty. In IIL, sovereignty is exercised when host States consent to investment protection standards contained in international investment agreements (IIAs). The legality of any subsequent State practice is restricted by reference to these standards. Over the last two decades alone, Chapter 11 of the North American Free Trade Agreement (NAFTA), ${ }^{1}$ the draft Multilateral Agreement on Investment ${ }^{2}$ and investment chapters in Free Trade Agreements such as the EU-Canada Comprehensive Economic and Trade Agreement ${ }^{3}$ have generated debate over the extent to which IIAs

* Lecturer in Law, Sussex Law School, University of Sussex, e.j.guntrip@sussex.ac.uk. The author would like to thank Stephen Allen, Stephanie Berry, Jo Bridgeman, Paul Eden, Colin King, Tarik Kochi, Aisling O'Sullivan and the anonymous reviewers for their comments on previous versions of this article. All errors and omissions remain the responsibility of the author.

1 North American Free Trade Agreement (adopted 17 December 1992, entered into force 1 January 1994) (1993) 32 ILM 289, 605 (NAFTA).

2 See N Wallace-Bruce, 'The Multilateral Agreement on Investment: An Indecent Proposal and Not Learning the Lessons of History' (2001) 2 Journal of World Investment 53.

${ }^{3}$ Full details are available at ec.europa.eu/trade/policy/in-focus/ceta/index_en.htm. 
delimit State sovereignty. ${ }^{4}$ Investment tribunals reinforce this approach to sovereignty when they prioritize the terms of IIAs over host State sovereign powers. As a result, investor-State dispute settlement (ISDS) has been decried as a means of permitting foreign investors to undermine host States' regulatory powers. ${ }^{5}$ In light of these discussions, this article presents a divergent view of how the term sovereignty is capable of being understood in IIL.

The concept of sovereignty is flexible and can be interpreted in a variety of ways in public international law. For example, a State can construe sovereignty so as to justify State conduct, whilst another State will refer to sovereignty to denounce the same act. ${ }^{6}$ According to Koskenniemi, debates over the meaning of legal terminology, such as sovereignty, reflect the nature of legal argumentation in public international law. ${ }^{7}$ International lawyers create legal arguments using the vocabulary of public international law to justify or criticize State conduct. ${ }^{8}$ As legal terms like sovereignty do not have a specific meaning, international lawyers seek to achieve political aims through varied interpretations of these terms. ${ }^{9}$ The use of legal terminology to mask a political agenda has implications when decision-makers are required to resolve a dispute. Given that legal terminology lacks fixed legal content, when decision-makers select their preferred argument, they are in effect, choosing a political position. ${ }^{10}$ Therefore, in public international law, terms such as sovereignty are used to pursue political aims which decision-makers endorse when deciding disputes.

Using this aspect of Koskenniemi's work, this article focuses on how decision-makers in IIL currently view sovereignty and promotes a viable alternative to the dominant interpretation of this term. It is asserted that decision-makers in IIL currently favour a normative approach to sovereignty by prioritizing legal standards in IIAs above the ability of the host State to regulate conduct within their jurisdiction. This interpretation reflects a specific political agenda within the IIL regime. This article presents an alternative political viewpoint and argues that sovereignty in IIL can be sourced from the will of the host State population. This understanding of sovereignty permits a host State to rely on factual and political justifications for its failure to comply with investment protection standards. As a result, sovereignty is not necessarily a legal concept that curtails host State conduct through the operation of IIAs. By using a new paradigm, this article

${ }^{4}$ See J Karl, 'International Investment Arbitration: A Threat to State Sovereignty?' in W Shan, P Simons and D Singh (eds), Redefining Sovereignty in International Economic Law (Hart Publishing 2008) 225; L Cotula, 'Do Investment Treaties Unduly Constrain Regulatory Space?' (2014) 9 Questions of International Law 19.

5 L Wells, 'Backlash to Investment Arbitration: Three Causes' in Waibel et al. (eds), The Backlash against Investment Arbitration: Perceptions and Reality (Kluwer 2010) 341.

${ }^{6}$ M Koskenniemi, From Apology to Utopia: The Structure of International Legal Argument (CUP 2005) 225. $\quad 7$ ibid 17, 59, 573. $\quad{ }^{8}$ ibid $566 . \quad 9$ ibid 570, 589.

${ }^{10}$ M Koskenniemi, 'Between Commitment and Cynicism: Outline for a Theory of International Law as Practice' in M Koskenniemi(ed), The Politics of International Law (Hart Publishing 2011) 281. 
challenges the presumptions underlying how sovereignty is currently understood in IIL and reconceptualizes its role in relation to foreign direct investment (FDI). To achieve its aims this article proceeds as follows. Part II outlines the theoretical framework by introducing ideas from Koskenniemi's writings that discuss the process of legal argumentation and decision-making in public international law. Part III argues that the currently accepted view of sovereignty in IIL emphasizes legal limitations above sovereign power in order to achieve the aims of the IIL regime. Part IV sets out an alternative understanding of sovereignty in IIL that is primarily sourced from the host State population exercising its right to economic self-determination. Part V justifies the adoption of this approach by reference to the growing trend for transparency during both the negotiation stages of IIAs and as part of ISDS. Part VI considers the wider implications of altering the foundations of sovereignty in IIL and submits that the proposed approach is unlikely to require wholesale changes to IIL. Conclusions are drawn in Part VII.

\section{REIMAGINING SOVEREIGNTY IN INTERNATIONAL INVESTMENT LAW}

Koskenniemi argues that the term sovereignty is ambiguous. ${ }^{11}$ He illustrates this point using the Rights of Passage case, ${ }^{12}$ in which both Portugal and India relied on the notion of sovereignty to support opposing positions. ${ }^{13}$ Given the disputing parties' contradictory application of the same concept, this dispute could not be resolved by reference to a singular definition of sovereignty. ${ }^{14}$ As such, sovereignty is capable of being comprehended in a variety of ways.

According to Koskenniemi, diverse interpretations of terms like sovereignty are attributable to the process of legal argumentation. ${ }^{15}$ International lawyers formulate legal arguments centred on principles of international law. ${ }^{16}$ They support their arguments using both law and fact, but will accentuate either fact or law to assert a particular viewpoint. ${ }^{17}$ International lawyers may emphasize facts by either distinguishing or drawing analogies with previous State conduct to support their claim. ${ }^{18}$ Alternatively, they may prioritize legal norms to challenge the 'unique' factual circumstances of the case. ${ }^{19}$ However, as illustrated by the Rights of Passage case, this approach to legal argumentation does not enable a dispute to be resolved. This is because it is impossible to reconcile legal and factual arguments regarding sovereignty ${ }^{20}$ as each position cancels the other out. ${ }^{21}$ Therefore, Koskenniemi maintains that neither legal nor fact-based arguments inherently prevail. ${ }^{22}$

\footnotetext{
11 Koskenniemi (n 6) 225, 226.

12 Case Concerning Right of Passage over Indian Territory (Portugal v India) (Merits) [1960] ICJ Rep 6. $\quad 13$ Koskenniemi (n 6) 241. $\quad 14$ ibid. 15 ibid 17, 59, 573.

16 ibid 566. 17 ibid 572. 18 ibid 59.

20 ibid 227-8; M Koskenniemi, 'The Politics of International Law' (1990) 1 EJIL 4, 8.

21 Koskenniemi (n 6) 65, 597; Koskenniemi (n 10) $272 . \quad{ }^{22}$ Koskenniemi (n 20) 16.
} 
As all legal argumentation is equally valid, differing interpretations of legal terms are plausible. On this basis, Koskenniemi concludes that the substantive content of legal principles such as sovereignty are incapable of possessing a fixed meaning. ${ }^{23}$ The indeterminacy of terms like sovereignty generates a weakness in every argument. If law is minimized in legal argumentation, international lawyers are claiming that State conduct is not regulated and that States are conferred with unrestrained power. ${ }^{24}$ Conversely, if law is prioritized, then international lawyers rely on norms that provide for idealized behaviour, which are not necessarily reflective of reality. ${ }^{25}$ Consequently, every legal argument can be critiqued for erring towards either the recognition of unregulated State power or the privileging of a legal norm. ${ }^{26}$

By prioritizing fact or law, international lawyers are able to tailor the content of legal principles to suit their argument. Koskenniemi contends that the practice of legal argumentation becomes a process by which international lawyers assert a political stance using a legal term as the foundation for their view $^{27}$ (often with reference to additional principles of international law to support their position). ${ }^{28}$ Therefore, sovereignty can being interpreted to support the exercise of State power to aid one political view, whilst it can also be construed to prevent the use of State power to achieve a different political aim. Which approach is taken in each instance will depend on the political interests of the State concerned. The legal arguments presented will broadly reflect the generally accepted, mainstream understanding of a term and minority positions that are regularly asserted to challenge the dominant viewpoint. $^{29}$

Decision-makers in public international law give preference to one argument over another. As each legal argument reflects a political agenda, decisionmakers are effectively selecting a political position. ${ }^{30}$ Therefore, in each case involving sovereignty, the decision-maker will either be permitting or denying the exercise of sovereignty to achieve a political goal. The decision made will be influenced by the argument presented, its unique context, the specific claim and how the particular audience views these contributing factors. ${ }^{31}$ Given the variability involved in each case, the outcome of legal disputes will oscillate between arguments that favour law and those that favour fact. ${ }^{32}$ When the political preferences of decision-makers result in the consistent adoption of an argument, the understanding of the legal term that

23 Koskenniemi (n 6) 62-3, 591; Koskenniemi (n 10) 275.

24 Koskenniemi (n 6) 60; Koskenniemi (n 20) 8.

25 Koskenniemi (n 6) 60; Koskenniemi (n 20) 8.

27 ibid 570, 589.

28 E Jouannet, 'Koskenniemi: A Critical Introduction' in M Koskenniemi (ed), The Politics of International Law (Hart Publishing 2011) 11.

29 Koskenniemi (n 6) 569, 572, 607; M Koskenniemi, 'International Law and Hegemony: A Reconfiguration', (2004) 17 Cambridge Review of International Affairs 197, 202.

30 Koskenniemi (n 10) 281.

32 ibid 65; Koskenniemi (n 29) 201.

31 Koskenniemi (n 6) 571. 
results will become the mainstream view. ${ }^{33}$ As nothing in international law is fixed, Koskenniemi stresses that the mainstream view is capable of shifting depending on the prevailing political circumstances. ${ }^{34}$

The decision made will additionally be guided by the structural bias that exists within the decision-making body. ${ }^{35}$ Koskenniemi identifies that the significance of structural bias has increased with the fragmentation of public international law, ${ }^{36}$ evidenced by the transition of power from States to regimes. ${ }^{37}$ As a result, international law is uniformly governed through specialist legal instruments ${ }^{38}$ that are administered by international bodies, each possessing a specific ethos. ${ }^{39}$ When presenting legal arguments, international lawyers (if they wish to succeed) must adopt the regime's unique terminology to ensure that their argument mirrors the aims of the regime. ${ }^{40}$ Structural bias results in decisions that favour State conduct that maximizes the outcome(s) that are deemed to be desirable by each specific regime. ${ }^{41}$ This predisposition dictates whether arguments that privilege law or fact are accepted. ${ }^{42}$ Therefore, as regimes seek to regulate States differently, how sovereignty is understood in each regime varies. As a result, the concept of sovereignty in IIL will have a particular understanding that mirrors the aims of the regime.

Despite each regime's leanings, Koskenniemi identifies that the indeterminacy that gives rise to legal argumentation is not dampened when power is transferred into legal regimes. ${ }^{43}$ Instead, each regime becomes 'a platform of disagreement' 44 where "prevailing "mainstreams" constantly clash against minority challengers' ${ }^{45}$ Therefore, it remains possible to challenge mainstream understandings of terms such as sovereignty within the IIL regime by presenting an interpretation that supports an alternative political perspective. As the mainstream view can evolve, should a minority narrative align with the changing political preferences of the regime, this interpretation has the potential to become the mainstream view.

33 Koskenniemi (n 6) 569-70.

34 ibid 570; Koskenniemi (n 29) 201.

35 Koskenniemi (n 6) 610 (some choices are 'methodologically privileged in the relevant institutions'); M Koskenniemi, 'The Fate of Public International Law: Between Technique and Politics' (2007) 70 MLR 1, 4; M Koskenniemi, 'Fragmentation of International Law: Difficulties Arising from the Diversification and Expansion of International Law', UN Doc A/CN.4/L.682 (2006) para 488.

36 M Koskenniemi, 'The Politics of International Law - 20 Years Later' (2009) 20 EJIL 7, 9.

37 ibid 12; M Koskenniemi, 'What Use for Sovereignty Today?' (2011) 1 AsianJIL 61, 65; Koskenniemi, 'Fragmentation of International Law' (n 35) para $487 . \quad 38$ Koskenniemi (n 37) 64.

39 M Koskenniemi, 'Conclusion: vocabularies of sovereignty - powers of a paradox' in $\mathrm{H}$ Kalmo and Q Skinner (eds), Sovereignty in Fragments: The Past, Present and Future of a Contested Concept (CUP 2010) 231; M Koskenniemi, 'Fragmentation of International Law' (n 35) para 488.

${ }^{40}$ For a description of this bias see M Koskenniemi, 'International Law: Constitutionalism, Managerialism and the Ethos of Legal Education' (2007) 1 European Journal of Legal Studies 1, 5.

41 M Koskenniemi, 'The Fate of Public International Law' (n 35) 6.

42 ibid 4, 6; Koskenniemi (n 36) 12.

44 Koskenniemi (n 39) 231.

43 Koskenniemi (n 36) 12.

45 Koskenniemi (n 36) 12. 
Koskenniemi's description of legal argumentation has been critiqued for failing to acknowledge the practice of public international law in its entirety. A key concern is that the examples used are extreme when compared to the general operation of public international law. ${ }^{46}$ For example, Koskenniemi's use of cases before international tribunals as illustrations of legal argumentation have been claimed to overstate his position as he neglects to consider consensual means of creating public international law. ${ }^{47}$ Additionally, it has been suggested that the political choice of the decision-maker is not as unfettered as Koskenniemi indicates given the structured (and potentially biased) environment in which the decision is made. ${ }^{48}$ Yet, despite these limitations, the essence of Koskenniemi's writings captures the manner in which legal terms are capable of multiple constructions. Whilst these interpretations will not always involve disputes that escalate to the level of adversarial cases before tribunals, they do force decision-makers to select their preferred political view (even if this is influenced by the institutional context in which the decision is being made). It is the availability of alternative understandings of legal terms that results from this practice, and the ensuing political choice between these alternatives, that forms the premise of this article.

In conclusion, whilst Koskenniemi's works are not accepted without question, they provide a framework to explain how legal argumentation and decision-making operate in public international law. This is founded upon the parity of legal argumentation and the indeterminacy of legal terms that preclude concepts like sovereignty from having a fixed definition. The indeterminacy of legal terminology permits international lawyers to use terms like sovereignty to pursue political aims. When disputes arise, decision-makers must decide between competing legal arguments, which require them to make a political choice. The decision-maker's political choice is influenced by the parameters and bias that apply to the decision-making body, which varies between different regimes in public international law. Consequently, the dominant interpretation of sovereignty in IIL reflects the structural bias and political aims of the IIL regime and its decision-makers. Most importantly for this article, Koskenniemi's approach advocates that legal principles in public international law are inherently capable of providing a 'vocabulary for articulating alternative preferences' ${ }^{49}$ As such, this article seeks to challenge the mainstream understanding of sovereignty in IIL by adopting a different political perspective to that currently employed in IIL. Prior to establishing this minority view, it is necessary to outline the mainstream view of sovereignty that currently dominates IIL.

\footnotetext{
46 R Higgins, Problems and Process: International Law and How We Use It (Clarendon Press 1994) 15.

47 V Lowe, 'Review: From Apology to Utopia: the Structure of International Legal Argument' (1990) 17 Journal of Law and Society 384, 387-8; D Bederman, 'From Apology to Utopia: the Structure of International Legal Argument' (1990) 23 NYUJIntLaw\&Pol 217, 224-5.

48 Jouannet (n 28) $28 . \quad 49$ Koskenniemi (n 37) 68.
} 
III. THE MAINSTREAM VIEW IN INTERNATIONAL INVESTMENT LAW: SOVEREIGNTY AS A LEGAL NORM

Investment tribunals refer to sovereignty in their awards, most commonly in the guise of a host State's right to regulate. In some instances, this is required as a direct response to explicit provisions in IIAs that create public policy exceptions to investment protection standards. ${ }^{50}$ In these cases, an investment tribunal is required to recognize the sovereign powers of the host State. Consequently, the decision reached will not necessarily reflect the political choice that the decision-maker would have made when exercising their judgment free from restraint. However, the right to regulate is also considered in the absence of explicit clauses ${ }^{51}$ giving an indication of how investment tribunals view the scope of host States' sovereign powers in general terms. By examining awards from the latter category, it is possible to understand how investment tribunals assess the residual role of sovereignty within IIL, identify whether fact or law is privileged in the decision-making process and determine how this influences the political choice made by decision-makers in IIL.

Some investment tribunals, such as the tribunal in ADC v Hungary, ${ }^{52}$ expressly privilege normativity within their reasoning. In the context of deciding the foreign investor's indirect expropriation claim, the tribunal in ADC v Hungary stated:

The Tribunal cannot accept the Respondent's position that the actions taken by it against the Claimants were merely an exercise of its rights under international law to regulate its domestic economic and legal affairs. It is the Tribunal's understanding of the basic international law principles that while a sovereign State possesses the inherent right to regulate its domestic affairs, the exercise of such right is not unlimited and must have its boundaries. As rightly pointed out by the Claimants, the rule of law, which includes treaty obligations, provides such boundaries. Therefore, when a State enters into a bilateral investment treaty like the one in this case, it becomes bound by it and the investment-protection obligations it undertook therein must be honored rather than ignored by a later argument of the State's right to regulate. ${ }^{53}$

In reaching their conclusion, this tribunal justified the limitations placed on host State sovereignty by reference to the 'rule of law'. In the manner described, the 'rule of law' equates to the host State being bound by the systemic operation of public international law. ${ }^{54}$ As such, binding sources of law, including IIAs, must delimit sovereign power. In taking this stance, the investment tribunal prioritized the understanding of sovereignty that privileges the legal framework above State conduct. The tribunal's position in $A D C$ was

50 C Titi, The Right to Regulate in International Investment Law (Hart Publishing 2014) ch VII.

51 ibid 275.

52 ADC Affiliate Limited and ADC \& ADMC Management Limited v Republic of Hungary, ICSID Case No ARB/03/16, Award, 2 October 2006 ( $A D C)$. $\quad 53$ ibid para 423.

54 See J Waldron, 'The Rule of International Law' (2006) 30 HarvJL\&PubPoly 15. 
endorsed by the tribunal in Occidental $v$ Ecuador ${ }^{55}$ and the notion of the 'rule of law' was also employed as a limitation on State sovereignty by the investment tribunal in Quiborax v Bolivia. ${ }^{56}$ In all of these decisions, the host State's arguments based on their sovereignty were unsuccessful. ${ }^{57}$ These awards indicate that when law is privileged above fact in the reasoning of an award, the political choice made by the decision-makers often favours the foreign investor.

Awards such as $A D C$, Occidental and Quiborax can be critiqued for their reliance on law. By privileging normativity, investment tribunals adopt the position that legal principles preclude State behaviour that does not conform to investment protection standards. Host State sovereignty is then limited accordingly. This position is not entirely defensible as, when taken to its logical conclusion, the legal framework will develop solely to achieve IIL's aims without regard to the factual circumstances being addressed by host States in the exercise of their sovereignty. If normativity is considered to be paramount, State practice will never give rise to boundaries and a legal ideal will result in which all States will be deemed to be able to comply with all principles of international investment law in any circumstances. Inherent State sovereignty will be excluded by IIAs to such a degree that its exercise by host States will be notional.

In contrast to the awards discussed above, more commonly, tribunals have highlighted that host States retain an inherent right to regulate. The S.D. Myers $v$ Canada, ${ }^{58}$ Saluka $v$ Czech Republic ${ }^{59}$ and Suez and InterAgua $v$ Argentina $^{60}$ awards expressly emphasize the ability of the host State to regulate in the context of expropriation. ${ }^{61}$ In relation to the fair and equitable treatment standard, the Plama v Bulgaria ${ }^{62}$ and Total v Argentina ${ }^{63}$ awards confirm that the host State's right to regulate remains a legitimate consideration for investment tribunals. ${ }^{64}$ Most strongly, the tribunal in Lemire v Ukraine ${ }^{65}$ required that 'the preferential treatment of foreigners be

55 Occidental Petroleum Corporation and Occidental Exploration and Production Company $v$ Republic of Ecuador, ICSID Case No ARB/06/11, Award, 5 October 2012 paras 529-530 (Occidental).

56 Quiborax S.A. and Non Metallic Minerals S.A. v Plurinational State of Bolivia, ICSID Case No ARB/06/2, Award, 16 September 2015, para 89.

$57 A D C$ (n 52) para 543; Occidental (n 55) para 876; ibid, para 626.

58 S.D. Myers, Inc. v Government of Canada, UNCITRAL, Partial Award, 13 November 2000 (S.D. Myers).

59 Saluka Investments B.V. v Czech Republic, UNCITRAL, Partial Award, 17 March 2006 (Saluka Investments).

60 Suez, Sociedad General de Aguas de Barcelona S.A. and Interagua Servicios Integrales de Agua S.A. v Argentine Republic, ICSID Case No ARB/03/17, Decision on Liability, 30 July 2010.

61 ibid paras 147-148; S.D. Myers (n 58) para 263; Saluka Investments (n 59) para 255.

62 Plama Consortium Limited v Republic of Bulgaria, ICSID Case No ARB/03/24, Award, 27 August 2008 (Plama Consortium Limited).

63 Total S.A. v Argentine Republic, ICSID Case No ARB/04/01, Decision on Liability, 27 December 2010. 64 ibid 123, 309; Plama Consortium Limited (n 62) para 177.

65 Joseph C. Lemire v Ukraine, ICSID Case No ARB/06/18, Decision on Jurisdiction and Liability, 21 January 2010. 
balanced against the legitimate right of Ukraine to pass legislation and adopt measures for the protection of what as a sovereign it perceives to be its public interest'. ${ }^{66}$

Despite these statements, Titi's review of investment awards that specifically recognize the sovereign power of the host State to regulate results in her identifying several trends ${ }^{67}$ that still evidence the privileging of normativity. The first trend noted by Titi is that there is no automatic presumption in favour of State sovereignty. ${ }^{68}$ This, to a certain extent, is to be expected, as the opposing views of the awards, highlighted so far, are reflective of the decision-making process explained by Koskenniemi. Every decision made will reflect the specific legal argumentation presented and take into account the context, nature of the claim and the audience ${ }^{69}$ (in this case, the composition of the investment tribunal). Therefore, investment awards will vary in terms of the weight given to specific factors. However, over the course of multiple awards, certain views will become prevalent and will form the mainstream narrative. ${ }^{70}$ Titi's assertion supports the view that the mainstream position in IIL is one that privileges legal restraints and minimizes the significance of State conduct.

Second, Titi identifies that the right to regulate is often qualified by terms such as 'reasonable' or 'legitimate'. ${ }^{71}$ This form of language implies that host States' sovereign powers have been curtailed by entering into an IIA. ${ }^{72}$ It is only those aspects of a host State's sovereignty that have not been limited by entering into an IIA that remain operational and are therefore 'reasonable' or 'legitimate'. Additionally, when applying these terms, tribunals prioritize their view of reasonableness above State conduct, thereby dismissing the sovereignty of the State. ${ }^{73}$ The imposition of limitations on sovereignty based on the legal framework and equitable notions provide further evidence that IIL favours legal obligations above State practice.

Finally, Titi highlights that an investment tribunal's recognition of a right to regulate does not necessarily translate into that right being upheld by the tribunal. ${ }^{74}$ The recognition of State sovereignty as an inherent power of the host State, followed by the subsequent failure of investment tribunals to base their decision on this inherent power, provides an additional indication that investment tribunals fail to privilege factual considerations when reaching their decisions. Therefore, these awards are also subject to the critique that they tend towards a legally dominated view of sovereignty in IIL.

The manner in which IIL understands sovereignty evidences a political choice by decision-makers to privilege law above fact. This approach is reflective of IIL's structural bias and political aims. When viewed from an IIL perspective, sovereignty reduces the efficiency of FDI by creating potential

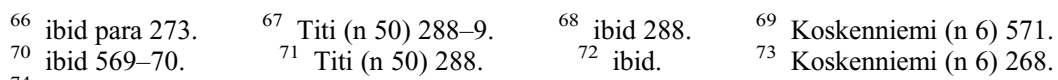

74 Titi (n 50) 288-9.
} 
barriers for foreign investors to maximize the profits from their investment. This attitude mirrors the 'neo-liberal' ideology that dominated IIL in the 1990s. ${ }^{75}$ It was during this time period that the first investment disputes were heard, ${ }^{76}$ and due to the continuing applicability of IIAs drafted at that time, this approach continues to apply today. ${ }^{77}$ 'Neo-liberalism' is a form of economic liberalism that seeks to minimize market interference, to the extent that States should not regulate beyond the protection of property rights. ${ }^{78}$ Consequently, the mindset of those implementing the regime is to seek to minimize the impact of host State conduct on the investment and to compensate the foreign investor when the investment is detrimentally affected by State conduct. To achieve this goal, the sovereign powers of a host State should be minimized as sovereignty is the origin of conduct that might have a detrimental effect on the investment. In so doing, investment tribunals consider the legal limitations placed on the host State's sovereignty by reference to the terms of the IIA. This achieves the 'optimal result' 79 for the IIL regime, which understands the role of the law as being to facilitate the regime's objectives and not to protect State sovereignty. ${ }^{80}$ For host States, the only defence they have against a foreign investor's claims that they have breached an IIA is to rely on their State sovereignty. ${ }^{81}$ Yet, through the establishment of the IIL regime, there has been a deferral of State power to decision-makers in IIL who consider State sovereignty as being limited by legal constraints. By prioritizing legal justifications, the decision-makers in IIL delimit the scope of a host State's sovereign power. $^{82}$ This minimizes the applicability of fact-driven approaches to sovereignty that support host State claims.

The practice of investment tribunals either expressly or implicitly privileges normativity over State conduct when addressing sovereignty in IIL. Tribunals such as $A D C$, Occidental and Quiborax specifically refer to a normative construct of sovereignty when they delimit sovereign power by reference to the rule of law. Tribunals that recognize a host State's sovereign right to regulate either implicitly condition sovereignty by reference to terms such as 'reasonable' or 'legitimate', or when making their political choice, privilege legal obligations. Both positions minimize the significance of State conduct and illustrate the preferred political choice of decision-makers in IIL. The political choice adopted may not be surprising in light of IIL's structural bias and the 'neo-liberal' political agenda that it follows. Nonetheless, in light of the consistent preference that is given to legal considerations over factual circumstances by investment tribunals when considering sovereignty, IIL is

\footnotetext{
75 S Spears, 'The Quest for Policy Space in a New Generation of International Investment Agreements' (2010) 13 JIEL 1037, 1040.

76 Asian Agricultural Products LTD (AAPL) v Republic of Sri Lanka, ICSID Case No ARB/87/

3, Final Award, 27 June 1990.
79 See Koskenniemi (n 29) 14.

80 See Koskenniemi (n 37) 65.

81 O Garcia-Bolivar, 'Sovereignty vs. Investment Protection: Back to Calvo?' (2009) 24 ICSID Review - Foreign Investment Law Journal 464, 465.

${ }^{82}$ Koskenniemi (n 37) 65.
} 
subject to the critique that it favours legal norms above host State sovereignty. As such, it can be countered by the argument that sovereignty in IIL can support a different political aim, that is, the exercise of host State sovereign power.

\section{AN ALTERNATIVE VIEW: SOVEREIGNTY BASED ON THE RIGHT TO ECONOMIC} SELF-DETERMINATION

Koskenniemi claims that that international legal discourse cannot fully accept any form of legal argumentation. ${ }^{83}$ Consequently, whilst the mainstream view of sovereignty in IIL that pursues 'neo-liberalism' can be justified to a certain extent, an alternative stance that supports the exercise of a host State's sovereign power is equally tenable. This section of the article sets out the foundations for this alternative argument by reference to the right to economic self-determination.

The adoption of self-determination as the basis for reimagining sovereignty in IIL is justifiable in light of the debates regarding economic self-determination that occurred during the 1960s and 1970s. These debates focused on the creation of a New International Economic Order (NIEO) which directly influenced the establishment of the modern IIL regime. The historical relationship between sovereignty, IIL and economic self-determination provides the foundation for an alternative view of sovereignty in IIL. ${ }^{84}$

The intersection of self-determination, sovereignty and IIL arose during the decolonization process. Whilst decolonization should have resulted in full independence for the newly decolonized developing States, they were discontent with their 'purely nominal political independence'. ${ }^{85}$ To achieve complete independence, developing States additionally sought economic decolonization. ${ }^{86}$ FDI contributed to the lack of economic independence of developing States. ${ }^{87}$ Foreign investors from developed States continued to export developing States' natural resources, ${ }^{88}$ and by so doing, denied developing States their sovereign rights over the resources and, as a corollary, their economic independence. ${ }^{89}$ In response, many developing States exercised their sovereignty to expropriate foreign investments. ${ }^{90}$

83 Koskenniemi (n 6) 60.

84 See Koskenniemi (n 20) 17-18 on the role of history in formulating alternative preferences.

85 M Bedjaoui, Towards a New International Economic Order (Holmes and Meier 1979) 85.

86 E McWhinney, 'The International Law-Making Process and the New International Economic Order' (1976) Canadian Yearbook of International Law 57, 60; K Sauvant, 'The Origins of the NIEO Discussions' in K Sauvant (ed), Changing Priorities on the International Agenda: The New International Economic Order (Pergamon Press 1981) 9.

87 The objectives of the World Bank were to restore economies affected by war to and to develop resources in less developed countries. One means of achieving these goals was FDI (R Blough, 'The World Bank Group' (1968) 22 Intl Org 152, 152).

${ }^{88} \mathrm{~K}$ Vandevelde, 'A Brief History of International Investment Agreements' (2005) 12 UCDavisJIntlL\&Poly 157, 166; K Miles, The Origins of International Investment Law: Empire, Environment and the Safeguarding of Capital (CUP 2013) 78.

${ }^{89}$ UNCTAD, Trends in International Investment Agreements: An Overview (1999) 16.

90 S Asante, 'International Law and Foreign Investment: A Reappraisal'(1988) 37 ICLQ 588, 594; Vandevelde (n 88) 166. 
To justify their actions, expropriating States used two legal principles in parallel; permanent sovereignty over natural resources and economic selfdetermination. ${ }^{91}$ By the mid-1960s, both of these concepts had been formulated as legal principles in United Nations General Assembly (UNGA) Resolution $1803^{92}$ and Common Article 1(2) of the International Covenant on Civil and Political Rights ${ }^{93}$ and the International Covenant on Economic, Social and Cultural Rights ${ }^{94}$ respectively. As a newly formulated right, ${ }^{95}$ economic self-determination provided a strong foundation for developing States to assert their sovereignty and to try and disrupt the colonial structures that underpinned FDI.

Whilst FDI was a significant hindrance for developing States, it was only one aspect of their broader goal of achieving economic parity. Developing States sought to create a NIEO to redistribute global wealth more equitably among States. ${ }^{96}$ To provide a legal basis for the proposed change, the NIEO was raised by developing States in the UNGA in $1974 .{ }^{97}$ This resulted in the generation of three UNGA Resolutions specifying what changes were required to establish a NIEO. ${ }^{98}$ It was in this context that further reforms to FDI were proposed. The Declaration on the Establishment of a $\mathrm{NIEO}^{99}$ and the Programme of Action on the Establishment of a NIEO ${ }^{100}$ contained, for example, a host State right to expropriate assets ${ }^{101}$ and permitted host States to review concession agreements. ${ }^{102}$ The Charter of the Economic Rights and Duties of States ${ }^{103}$ included, amongst other things, a domestic measure of compensation for expropriation and removed the requirement that the expropriation was to be undertaken for a public purpose. ${ }^{104}$ These resolutions specifically relied on the right to economic self-determination to achieve these aims. ${ }^{105}$ Thus, economic self-determination provided the foundation for sovereign acts affecting FDI.

91 A Anghie, Imperialism, Sovereignty and the Making of International Law (CUP 2004) $211,212$.

92 Permanent Sovereignty over Natural Resources, UNGA Res 1803 (XVII) (14 Dec 1962) UN Doc A/5217.

93 International Covenant on Civil and Political Rights (adopted 16 December 1966, entered into force 23 March 1976) 999 UNTS 171 (ICCPR).

94 International Covenant on Economic, Social and Cultural Rights (adopted 16 December 1966, entered into force 3 January 1976) 993 UNTS 3 (ICESCR).

95 G Simpson, 'The Diffusion of Sovereignty: Self-Determination in the Post-Colonial Age' (1996) 32 StanJIntlL 255, 268.

96 N Gilman, 'The New International Economic Order: A Reintroduction' (2015) 6 Humanity 1,4 .

97 These were in the Sixth Special Session and the Twenty-Ninth Regular Session of the United Nations General Assembly.

98 Declaration on the Establishment of a New International Economic Order, UNGA Res 3201 (S-VI) (1 May 1974) UN Doc A/RES/S-6/3201 (Declaration); Programme of Action on the Establishment of a New International Economic Order, UNGA Res 3202 (S-VI) (1 May 1974) UN Doc A/RES/S-6/3202 (Programme); Charter of Economic Rights and Duties of States, UNGA Res 3281 (XXIX) (12 December 1974) UN Doc A/RES/29/3281 (CERDS).

\footnotetext{
99 Declaration (n 98). $\quad{ }_{100}$ Programme (n 98). $\quad{ }_{101}$ Declaration (n 98) art 4(g).

102 Programme (n 98) section V(b). $\quad{ }_{103}$ CERDS (n 98). $\quad{ }_{104}$ ibid art 2(2)(c).

105 ibid arts 1, 2(1); Declaration (n 98) arts 4(a), 4(d), 4(e); Programme (n 98) section VIII.
} 
The position taken by developing States in these UNGA Resolutions was contentious, partly due to the altered foundations of the law on expropriation. ${ }^{106}$ As a result, developed States did not vote in favour of the NIEO and dismissed its content as it did not comply with established standards of international law. ${ }^{107}$ This enabled developed States to maintain their standing in the international and economic arenas, ${ }^{108}$ and the NIEO did not materialize. ${ }^{109}$ However, the NIEO was not without impact. The changes to FDI proposed by developing States during the NIEO generated significant legal uncertainty ${ }^{110}$ and risk for foreign investors, especially in relation to the threat of expropriations. ${ }^{111}$ Accordingly, treaties were used to regulate State conduct that was likely to affect foreign investors. ${ }^{112}$ This process generated the contemporary treaty based IIL regime. ${ }^{113}$ As such, the right to economic self-determination (as a justification for exercising sovereign rights over FDI) is intrinsically linked to IIL.

The historical relationship between sovereignty, IIL and economic selfdetermination is significant for two reasons. First, the intersection between IIL and the right to economic self-determination permits legal argumentation based on the right to self-determination within the IIL regime. IIL is a specialist regime within public international law that has developed its own structural bias. ${ }^{114}$ Consequently, investment tribunals are likely to dismiss arguments that rely on concepts that are external to the regime. ${ }^{115}$ Arguments based on human rights that are linked to IIL, such as the protection of property interests or the right to a fair trial, have been accepted by investment tribunals. ${ }^{116}$ Hence, given the pre-existing association between IIL and the right to self-determination, legal arguments that rely on the right to economic self-determination as the basis for sovereignty are capable of falling within the scope of IIL's specialist focus.

Secondly, and more fundamentally, the historical relationship between IIL and economic self-determination illustrates the extent to which the current understanding of sovereignty in IIL restricts the economic independence of

\footnotetext{
106 See, for example, J Gamble Jr and M Frankowska, 'International Law's Response to the New International Economic Order: An Overview' (1986) 9 BCIntl\&CompLRev 257, 265-8.

107 A Newcombe and L Paradell, Law and Practice of Investment Treaties (Kluwer Law International 2009) 32.

108 M Salomon, 'From NIEO to Now and the Unfinishable Story of Economic Justice' (2013) 62 ICLQ 31, 46.

110 R Dolzer and C Schreuer, Principles of International Investment Law (OUP 2012) 5.

111 Vandevelde (n 88) 169. ${ }^{112}$ Miles (n 88) 84. ${ }^{113}$ Newcombe and Paradell (n 107) 41-9.

114 See section III above.

115 See Border Timbers Limited, Border Timbers International (Private) Limited, and Hangani Development Co. (Private) Limited v Republic of Zimbabwe, ICSID Case No ARB/10/25, Procedural Order No 2, 26 June 2012, paras 57-59; Bernhard von Pezold and others v Republic of Zimbabwe, ICSID Case No ARB/10/15, Procedural Order No 2, 26 June 2012, paras 57-59.

116 See CMS Gas Transmission Company v Republic of Argentina, ICSID Case No ARB/01/8, Award, 12 May 2005 para 121; Hesham Talaat M. Al-Warraq v Republic of Indonesia, UNCITRAL, Final Award, 15 December 2014 paras 556-605; Tulip Real Estate and Development Netherlands B.V. v Republic of Turkey, ICSID Case No ARB/11/28, Decision on Annulment, 30 December 2015, para 92.
} 
many host States. The motivation behind the NIEO was to provide newly decolonized States with economic freedom through the independent exercise of their sovereign powers. ${ }^{117}$ Instead of the NIEO, a Washington Consensus driven economic model was adopted in IIL. ${ }^{118}$ Due to the lack of alternative sources of finance, ${ }^{119}$ the widespread acceptance of FDI in accordance with this economic model resulted in the imposition of a market ideology on the economies of many States. ${ }^{120}$ This undermined the economic sovereignty of these States and restricted their economic independence. Further, the mainstream view of sovereignty in IIL based on 'neo-liberalism' has continued to stifle the economic independence of host States (both developing and developed) by delimiting State powers. Hence, the scope of host State economic policies is also dictated by IIAs, preventing the full exercise of their right to economic self-determination. The limitations currently imposed by IIL on a host State's sovereign power generate the need for a contrary political outlook in IIL. Therefore, a political perspective that empowers host States forms the basis of the proposed, alternative understanding of sovereignty in IIL.

The formulation of sovereignty in IIL suggested in this article significantly differs from the arguments presented by developing States during the NIEO. The factual and political changes that generated the understanding of sovereignty during the 1960s and 1970s were specific to the transformations brought about by the decolonization process. The economic independence of developing States from their former colonial powers provided the central focus of the legal arguments presented to the international community. In a postcolonial setting, these arguments become less compelling. Further, the validity of the arguments presented during the NIEO may be questionable even in the context of decolonization given their requirement for wholesale global economic change. ${ }^{121}$ In contrast, the formulation of sovereignty proposed in this article focuses not on economic independence from former colonial powers, but the ability of a host State population to determine its own economic agenda. This approach applies equally to populations in developing and developed States. Relying on the mandate of the host State population as the source of sovereign power, rather than limiting sovereign power by reference to legal norms, can generate a new understanding of sovereignty in IIL when based on the right to economic self-determination.

Whilst all legal argumentation necessarily requires reference to principles of international law, ${ }^{122}$ the argument that sovereignty is based on the right to economic self-determination infers that economic self-determination has a

\footnotetext{
117 Gilman (n 96) 4.

118 J Salucuse, 'The Treatification of International Investment Law' (2007) 13 Law and Business Review of the Americas 155, 160.

119 ibid 159; K Vandevelde, Bilateral Investment Treaties: History, Policy and Interpretation (OUP 2010) 62.

120 Salomon (n 108) 35.

121 B Saul, D Kinley and J Mowbray, The International Covenant on Economic, Social and Cultural Rights: Commentary, Cases and Materials (OUP 2014) $57 . \quad 122$ Jouannet (n 28) 11.
} 
distinct meaning. However, the term self-determination is itself indeterminate and, therefore, attempts to confer this right with meaning will reflect the privileging of fact or law. As this remains an unavoidable aspect of legal argumentation, the view of economic self-determination proposed will reflect a mainstream understanding of the concept. ${ }^{123}$

In a postcolonial context, the continued role of the right to self-determination was questioned. ${ }^{124}$ However, reference to the right to self-determination in legal instruments ${ }^{125}$ and its application by international ${ }^{126}$ and domestic courts, ${ }^{127}$ as well as to various States ${ }^{128}$ beyond the context of decolonization indicates that the right retains a significant (if not contested) function in public international law. ${ }^{129}$ The postcolonial use of the right to self-determination suggests that the right must be interpreted to mean something more than giving rise to independence from former colonial powers. ${ }^{130}$ Therefore, it is essential to identify the contemporary role of self-determination in international law in order to understand how economic self-determination can enable an alternative view of sovereignty in IIL. Given the indivisibility of the right to self-determination, ${ }^{131}$ economic self-determination is linked to the right to political self-determination. Hence, this article proceeds on the premise that economic self-determination can be considered to be an ongoing right that offers 'peoples' the ability to choose their domestic economic policies through constitutional and political processes.

The essence of the right to self-determination is the element of free choice. ${ }^{132}$ Although this choice was for political independence during the colonial era, the

123 See M Koskenniemi, 'National Self-Determination Today: Problems of Legal Theory and Practice’ (1994) 43 ICLQ 241.

${ }^{124}$ C Drew, 'The East Timor Story: International Law on Trial' (2001) 12 EJIL 651, 658; M Saul, 'The Normative Status of Self-Determination in International Law: A Formula for Uncertainty in the Scope and Content of the Right?' (2011) 11 HRLRev 609, 614.

125 In instruments including ICCPR (n 93) and ICESCR (n 94) common art 1; Declaration on Principles of International Law concerning Friendly Relations and Cooperation among States in accordance with the Charter of the United Nations, UNGA Res 2625 (XXV) (24 October 1970) UN Doc A/RES/2625 (Friendly Relations Declaration); The Final Act of the Conference on Security and Cooperation in Europe (1 August 1975) 14 ILM 1292 (Final Act); African Charter on Human and Peoples' Rights (adopted 27 June 1981, entered into force 21 October 1986) (1982) 21 ILM 58 (African Charter); Vienna Declaration and Programme of Action (12 July 1993) UN Doc A/ CONF.157/23 (Vienna Declaration). See also CCPR, 'General Comment no 12' on 'Compilation of General Comments and General Recommendations Adopted by Human Rights Treaty Bodies’ (13 March 1984) UN Doc HRI/GEN/1/Rev.1 at 12, para 1 (General Comment 12).

${ }^{126}$ Case Concerning East Timor (Portugal v Australia), Merits, Judgment of 30 June 1995, [1995] ICJ Rep 90; Legal Consequences of the Construction of a Wall in the Occupied Palestinian Territory, Advisory Opinion, 9 July 2004, [2004] ICJ Rep. 136.

127 Re Secession of Quebec [1998] 2 SCR 217.

128 Such as Bangladesh, Czechoslovakia, Eritrea, Soviet Union, former Yugoslavia and Kosovo.

129 Saul, Kinley and Mowbray (n 121) 614.

130 Accordance with International Law of the Unilateral Declaration of Independence in Respect of Kosovo, Advisory Opinion, 22 July 2010, [2010] ICJ Rep 403, para 82.

131 Saul, Kinley and Mowbray (n 121) 59.

132 Western Sahara, Advisory Opinion, 16 October 1975, [1975] ICJ Rep 12, para 55. See also A Cassese, Self-Determination of Peoples: A Legal Reappraisal (CUP 1995) 101. 
exercise of the right to self-determination did not require this outcome. ${ }^{133}$ As a result, the right to self-determination is not tied to independence but it is linked to choice regarding the political and economic systems of a State, as well as the social and cultural practices adopted by its population. ${ }^{134}$ Therefore, economic self-determination provides for a choice between different economic systems. ${ }^{135}$

The choice is usually exercised through electing a representative government. ${ }^{136}$ In accordance with this view, a host State population will have mandated the economic policies of an elected government. ${ }^{137}$ When circumstances change, the government can rely on the existing mandate or alter their mandate to address the specific situation. ${ }^{138}$ To provide the State's population with a choice, the right to economic self-determination entails a duty of transparency. ${ }^{139}$ This requires that a State provide its population with access to relevant information. ${ }^{140}$ As a result, economic self-determination requires an interface between the government and the population it represents. Rather than providing for substantive rights, ${ }^{141}$ economic selfdetermination can be seen as a right to a process by which a State's population is consulted regarding future economic policies. ${ }^{142}$ Therefore, although some elements of substance precondition the right, ${ }^{143}$ economic self-determination can be framed more procedurally than substantively. ${ }^{144}$ The applicable procedures are usually contained in the constitution and political processes of the State. ${ }^{145}$ The constitutional and political processes of the State can be broadly construed. Although the specific processes will vary from State to State, they can include elections, referenda, judicial review, formal and informal consultation mechanisms, petitions, public protests and attendance at public meetings. ${ }^{146}$ In essence, the host State

133 Higgins (n 46) 118, 119.

134 ICCPR (n 93) and ICESCR (n 94), common art 1; Friendly Relations Declaration (n 123); Final Act (n 123); African Charter (n 123). $\quad 135$ Saul, Kinley and Mowbray (n 121) 59.

136 This is not necessarily tied to a right to democracy. See Friendly Relations Declaration (n 123); Higgins (n 46) 120.

137 B Manin, A Przeworski and S Stoke 'Elections and Representation' in B Manin, A Przeworski and S Stoke, Democracy, Accountability and Representation (CUP 1999) 30.

138 ibid 35-6. $\quad 139$ Saul, Kinley and Mowbray (n 121) 67.

140 CESCR, Concluding Observations: Azerbaijan, E./C.12/1/Add.20 (22 December 1997) para 29.

141 See Legal Consequences for States of the Continued Presence of South Africa in Namibia (South West Africa) Notwithstanding Security Council Resolution 276 (1970), Advisory Opinion, [1971] ICJ Rep 16, para 52 which focuses on the outcome of independence.

142 Drew (n 124) 658, 659; David Raič, Statehood and the Law of Self-Determination (Brill 2002) 237. 143 Drew (n 124) 663.

144 J Klabbers, 'The Right to be Taken Seriously: Self-Determination in International Law' (2006) HumRtsQ 186, 189, 202, 203.

145 General Comment 12 (n 125) para 4. See D Sarooshi, International Organisations and the Exercise of Sovereign Powers (2005) 9-10 on the need for sovereign power to align with sovereign values.

146 See Oxford Pro Bono Publico, A Comparative Survey of Public Participation in the Legislative Process - Report for the National Campaign for People's Right to Information 
population must be permitted to express their view as to which economic policy is their preferred choice through legitimate constitutional and political means. This constitutional relationship provides the link between sovereignty and economic self-determination. ${ }^{147}$ The sovereign powers of the State must be exercised in a manner that correlates with the choice of the population so as to give effect to the right to economic self-determination. The government can be held accountable in accordance with the constitution should they fail to do so. ${ }^{148}$

To enable choice, and to hold the government to account, the right to selfdetermination needs to function as a continuing right. ${ }^{149}$ The formulation of the right in various legal texts suggests that the right is an ongoing one. ${ }^{150} \mathrm{It}$ cannot be presumed that political, social, cultural and economic aspects of the State are to be fixed at the time of political independence of the State. ${ }^{151}$ This would undermine the independence of the newly formed State as demonstrated by the concerns raised by newly independent States prior to debating the creation of the NIEO. Further, the continuing nature of the right aligns with the procedural nature of economic self-determination that is tied to constitutional systems. As stated by the Canadian Supreme Court in Reference re Secession of Quebec from Canada: ${ }^{152}$

[t]he recognized sources of international law establish that the right to selfdetermination is normally fulfilled through internal self-determination - a people's pursuit of its political, economic, social and cultural development within the framework of an existing state. ${ }^{153}$

Whereas self-determination has classically been conceived as a justification for the existence of a State, ${ }^{154}$ the postcolonial right to economic self-determination is conferred upon 'peoples'. ${ }^{155}$ Consequently, the right to self-determination is clearly not a right of the State. ${ }^{156}$ Therefore, the free choice that is exercisable in accordance with self-determination should be distinguished from rights possessed by States such as sovereign equality and non-intervention. ${ }^{157}$

(2011) available at <www3.law.ox.ac.uk/denning-archive/news/events_files/A_Comparative_ Survey_of_Public_Participation_in_the_Legislative_Process.pdf $>$.

147 J Summers, 'The Internal and External Aspects of Self-Determination Reconsidered' in D French (ed), Statehood and Self-Determination: Reconciling Tradition and Modernity in International Law (CUP 2013) 237.

148 Raič (n 142) 272-3.

149 Cassese (n 132) 101; P Thornberry, 'The Democratic or Internal Aspect of SelfDetermination with Some Remarks on Federalism' in C Tomuschat (ed), Modern Law of Self-Determination (Martinus Nijhoff 1993) 101, 119; Higgins (n 46) 120.

${ }_{150}$ Cassese (n 132) 128; Raič (n 142) 228.

152 Re Secession of Quebec [1998] 2 SCR 217.

154 Koskenniemi (n 123) 245-6

155 ICCPR (n 93) and ICESCR (n 94) art 1(2). See Cassese (n 132) 143.

156 J Crawford, The Rights of Peoples (Clarendon Press 1988) 59.

157 Raič (n 142) 233; A Rosas 'Internal Self-Determination' in C Tomuschat (ed), Modern Law of Self-Determination (Martinus Nijhoff 1993) 228-9. 
Although not a State right, economic self-determination is exercisable within the constitutional framework of the State. ${ }^{158}$ Therefore, the constitutional processes must enable the State to consider the views of 'peoples'. There are divergent views of who constitutes a 'peoples' for the purposes of the postcolonial operation of the right to economic self-determination. ${ }^{159}$ One view supports the stance that 'peoples' should be linked to the territory of the State $^{160}$ and, consequently, should constitute the entire population of the State. ${ }^{161}$ This interpretation does not automatically accord with the use of 'all peoples' in Common Article 1 as it does not refer to nations, ${ }^{162}$ although subsequent instruments ${ }^{163}$ have indicated acceptance of this approach. Further, if the whole population is consulted, majoritarian views will prevail, denying self-determination to minority and indigenous groups. ${ }^{164}$ Conversely, if self-determination only focuses on minorities and indigenous groups in the traditional sense, ${ }^{165}$ this denies the majority from being able to contribute to the economic future of the State. ${ }^{166}$ To balance these approaches, it is suggested that the whole population should be given the power to determine the economic policies of the State. However, to ensure that majoritarian considerations are not automatically prioritized, constitutional consultation mechanisms need to be utilized to provide an effective means for minorities and indigenous populations to be able to contribute to the debate. ${ }^{167}$ These mechanisms must respect principles such as the need to obtain free, prior, informed consent from indigenous populations. ${ }^{168}$

Translating this approach to IIL, economic self-determination is an ongoing right that offers choice to the host State population to determine their domestic economic policies. This is to be achieved through the use of constitutional procedures that require consultation with the host State population, whilst ensuring that minority groups and indigenous populations are also heard.

158 Raič (n 142) 239.

159 H Quane, 'The United Nations and the Evolving Right to Self-Determination' (1998) 47 ICLQ 537, 537.

${ }^{160} \mathrm{H}$ Hannum, Autonomy, Sovereignty and Self-Determination: The Accommodation of Conflicting Rights (Pennsylvania Press 1990) 36; Rosas (n 157) 244.

161 General Comment 12 (n 125) paras 1 and 4. See R McCorquodale, 'Self-Determination: A Human Rights Approach’ (1994) 43 ICLQ 857, 866; Cassese (n 132) 102.

162 Raič (n 142) 245.

163 Friendly Relations Declaration (n 123) (refers to 'a government representing the whole people belonging to the territory'); travaux preparatoires to Final Act (n 123) Principle VIII, see ibid 246.

164 McCorquodale (n 161) 868; Thornberry (n 149) 127; Klabbers (n 144) 203. See CERD, 'General Recommendation no 21' on 'Right to Self-Determination' (23 August 1996) UN Doc A/51/18, annex VIII at 125, paras 4 and 5 (General Recommendation 21).

165 That is, for minorities, people linked by ethnic, religious or linguistic ties and for indigenous peoples, descendants from populations present in a region prior to invasion or colonial occupation and who maintain their own identity. See Higgins (n 46) 124.

166 There should not necessarily be a veto power. See Klabbers (n 144) 203.

167 ibid; Thornberry (n 149) 127-8. See General Recommendation 21 (n 164) paras 4 and 5.

168 UNHRC, United Nations Declaration on the Rights of Indigenous Peoples (9 December 2007) UN Doc A/61/L.67/Annex, arts 10, 19 and 32. 
Provided these conditions are met a host State is conferred with a mandate that justifies their State practice. ${ }^{169}$ This foundation provides the basis for a factually driven understanding of sovereignty in IIL. When a host State population exercises its right to economic self-determination, it is selecting the economic model that it considers to be the most appropriate for the State. In so doing, it is acting in the political sphere of the host State. The choice made during this process provides the mandate within which the host State government must act, which determines how the government's sovereign power should be exercised. Therefore, when the right to economic self-determination is exercised, the origins of the host State's sovereign power can be sourced in the factual and political realm enabling an understanding of sovereignty that privileges fact over law. The arguments regularly presented by host State governments in IIL disputes are based on domestic policies that are intended for the betterment of the host State population. Should fact be privileged when addressing sovereignty in IIL, this would permit host States to refer to the choice of economic policy made by their population as a justification for their conduct, thereby relying on the notion of sovereignty.

The adoption of this alternative understanding of sovereignty in IIL confers host State arguments with greater credibility. If a host State's sovereign act(s) could be justified as the exercise of the host State population's right to economic self-determination, it would be more challenging for a decision-maker to dismiss a host State's argument given the international recognition of this right. Investment protection standards could be reinterpreted to take into account the factual and political justifications that gave rise to the host State's exercise of sovereign power, which forms the basis of the dispute. Decisionmakers in IIL could generate exceptions to investment protection standards and limit the mainstream, normative construction of sovereignty. Even though relying on a factual understanding of sovereignty may strengthen the host State's argument, the final outcome of any dispute would still be resolved by the decision-maker's political choice. This allows decisionmakers to continue to support a normative understanding of sovereignty. Yet, when privileging normativity, a decision-maker would be simultaneously denying the right of economic self-determination to the host State population. Given this consequence, decision-makers may be more reluctant to adopt legally driven understandings of sovereignty in IIL.

Similarly to the mainstream view, the suggested approach to sovereignty in IIL can be critiqued. In particular, the proposed view can be countered by referring to the ability of host States to ignore the normative framework that governs IIL on the basis of the mandate of their population. This view arguably could be used to deny the operation of all investment protection

169 A Cristecu, The Right to Self-Determination: Historical and Current Development on the Basis of United Nations Instruments (1981) UN Doc E/CN.4/Sub.2/404/Rev.1, 119. 
standards. As such, it would lead to sovereignty being used as an excuse for the unlimited exercise of State power. ${ }^{170}$ This criticism is valid, however, the use of a legal understanding of sovereignty can deny a host State from exercising its sovereignty when it needs to act in the best interests of its population. In accordance with Koskenniemi's views, neither argument inherently prevails, ${ }^{171}$ so the criticisms that can be levelled at a factual understanding of sovereignty are equally as valid as the criticisms levelled at the normative approach. Therefore, the mainstream approach and the alternative view are equally justifiable.

The formulation of an alternative view of sovereignty in IIL based on the right to economic self-determination is founded on a political view that permits host States to exercise sovereign powers. It reflects a factually driven understanding of sovereignty. The adoption of this standpoint is validated by reference to the historical development of the international investment law regime. It relies upon a postcolonial understanding of economic self-determination, which provides for an ongoing right that offers 'peoples' the ability to choose their domestic economic policies through constitutional and political processes. Although erring towards unlimited State power, the suggested understanding of sovereignty is equally as valid as a normative approach to sovereignty. It is on this basis that the use of sovereignty in IIL can be reimagined. The proposed approach to sovereignty counters the mainstream understanding of this term and undermines the current universality of the dominant approach to sovereignty in IIL. It highlights the limited conception of sovereignty that is applied in IIL. This alternative narrative permits an unrestrained view of sovereignty to be espoused within IIL. This can facilitate a broader understanding of the legal framework that governs IIL. Further, as international law is not fixed, ${ }^{172}$ and mainstream views are capable of change, ${ }^{173}$ this alternative approach has the potential to become the mainstream view in IIL. However, this is dependent on the prevailing political circumstances. ${ }^{174}$ Therefore, for this view to be adopted, the political climate must warrant an investment tribunal considering and adopting this new political position. The current political climate surrounding IIL suggests that the proposed, alternative understanding of sovereignty is the most appropriate political choice for investment tribunals.

\section{V. 'A GROWING TREND': TRANSPARENCY IN INTERNATIONAL INVESTMENT LAW}

The politics surrounding IIL have centred on the ability of foreign investors to invoke IIAs to challenge host State conduct in a private dispute resolution forum. In response, there is 'a growing trend' towards transparency in IIL. ${ }^{175}$

170 Koskenniemi (n 6) 60.

173 ibid 570; Koskenniemi (n 29) 201.

171 ibid.

172 ibid 570 . 174 ibid.

175 R Hofmann and C Tams, The International Convention on the Settlement of Investment Disputes (ICSID): Taking Stock after 40 Years (Nomos 2007) 197; S Schill, 'Editorial: Five Times Transparency in International Investment Law' (2014) 15 Journal of World Investment 
This trend supports the adoption of the alternative understanding of sovereignty in IIL proposed in this article. This is because transparency in IIL permits host State populations to have access to the necessary information to choose their preferred economic policy. As such, it enables the exercise of economic selfdetermination and increases the accountability of the IIL regime. ${ }^{176}$

Transparency can take a variety of forms in IIL. ${ }^{177}$ For the purposes of this article, the discussion of transparency will focus on how a host State population can be informed of developments in IIL that are likely to influence their choice of economic policy when exercising their right to economic self-determination. The first aspect of transparency that will be addressed is the means by which a host State population can become aware of the details of investment disputes. The second element to be considered will be the dissemination of information to the host State population regarding the negotiation of IIAs.

Due to its commercial arbitration origins, ${ }^{178}$ investor-State dispute settlement (ISDS) has traditionally been confidential. This has precluded host State populations from attending the dispute settlement process without party consent, ${ }^{179}$ viewing supporting documents ${ }^{180}$ and, in some instances, accessing investment awards. ${ }^{181}$ However, the introduction of transparency procedures in NAFTA ${ }^{182}$ resulted in the adoption of transparency provisions in other IIAs. ${ }^{183}$ This general move towards transparency was further bolstered in 2014 when UNCITRAL produced a tailored structure for

and Trade 363, 363; J Calamita, 'Dispute Settlement Transparency in Europe's Evolving Investment Treaty Policy: Adopting the UNCITRAL Transparency Rules Approach' (2014) 15 Journal of World Investment and Trade 645, 646, 653, 676.

176 Koskenniemi (n 37) 68; Hofmann and Tams (n 175) 208.

177 See F Ortino 'Transparency of Investment Awards: External and Internal Dimensions' in J Nakagawa (ed), Transparency in International Trade and Investment Dispute Settlement (Routledge 2013) 119; A Asteriti and C Tams, 'Transparency and Representation of the Public Interest in Investment Treaty Arbitration' in S Schill (ed), International Investment Law and Comparative Public Law (OUP 2010) 787; Calamita (n 173) 649.

178 Hofmann and Tams (n 175) 184-5; S Schill, 'Public or Private Dispute Settlement? The Culture Clash in Investment Treaty Arbitration and Its Impact on the Role of the Arbitrator' in T Weiler and F Baetens (eds), New Directions in International Economic Law: In Memoriam Thomas Walde (Brill 2011) 23.

179 ICSID Rules of Procedure for Arbitration Proceedings, (January 2003) Doc ICSID/15/Rev. 1 rule 32(2) (ICSID Arbitration Rules); UNCITRAL Arbitration Rules (15 December 1976 as revised in 2010) UN Doc A/RES/31/98 and UN Doc A/RES/65/22, art 28(3) (UNCITRAL Arbitration Rules).

${ }^{180}$ Biwater Gauff (Tanzania) Limited v United Republic of Tanzania, ICSID Case No ARB/05/ 22, Procedural Order No 3, 29 September 2006, para 157 (Biwater).

181 ICSID Arbitration Rules (n 179) rule 48(4) and Convention on the Settlement of Investment Disputes between States and Nationals of Other States (adopted 18 March 1965, entered into force 14 October 1966) 575 UNTS 159, art 48(5) (ICSID Convention); UNCITRAL Arbitration Rules (n 179) art 34(5).

182 NAFTA (n 1) Annex 1137.4; NAFTA Free Trade Commission, Notes of Interpretation on Certain Chapter 11 Provisions, 31 July 2001; NAFTA Free Trade Commission, Joint Statement, 16 July 2004.

183 For example, 2004 US Model BIT, art 29; 2012 US Model BIT art 11; 2004 Canadian Model FIPA art 38; Australian-Chile FTA art 10.22. 
creating transparency in ISDS. This structure enables a host State population to exercise its right to economic self-determination.

UNCITRAL's recent initiative on transparency has significantly widened the scope of transparency in ISDS. First, the UNCITRAL Rules on Transparency in Treaty-based Investor-State Arbitration (Transparency Rules) ${ }^{184}$ create a presumption of increased transparency in ISDS for disputes ${ }^{185}$ for IIAs that have been entered into since 1 April 2014. ${ }^{186}$ Disputing parties are required to disclose the notice of arbitration, ${ }^{187}$ submissions and arbitral awards. ${ }^{188}$ The duty does not apply if the parties opt out, ${ }^{189}$ or if information is confidential (or protected) or is contrary to essential security interests. ${ }^{190}$ This presumption counters both the traditional confidentiality of ISDS and the neutral stance that has been adopted by investment tribunals more recently on the issue of transparency. ${ }^{191}$ Although automatically applying to disputes governed by the UNCITRAL Arbitration Rules, the Transparency Rules can apply to arbitrations conducted in accordance with other arbitration rules (for example, the ICSID Arbitration Rules). ${ }^{192}$ Consequently, UNCITRAL's framework has the potential to significantly alter the transparency of proceedings across all forms of ISDS. The Transparency Rules are supplemented by the United Nations Convention on Transparency in Treatybased Investor-State Arbitration (Mauritius Convention) ${ }^{193}$ that permits States to apply the Transparency Rules in disputes involving IIAs entered into prior to 1 April 2014. ${ }^{194}$ For the Mauritius Convention to apply, the home and host State must be signatories, in which case the Transparency Rules are mandatory. ${ }^{195}$ Alternatively, they can apply with host State and foreign investor agreement. ${ }^{196}$ Given that most investment disputes will be governed by IIAs entered into before 1 April 2014, the scope of application of the Transparency Rules is considerably widened by the operation of the Mauritius Convention. Finally, all documents that have been disclosed will be placed on the Transparency Registry run by UNCITRAL. ${ }^{197}$ The creation of a central repository for this information streamlines the process of retrieving publicly accessible materials relating to investment disputes.

The combination of the Transparency Rules, the Mauritius Convention and the Transparency Registry reflects a significant transition towards transparency

184 UNCITRAL Rules on Transparency in Treaty-based Investor-State Arbitration (16 December 2013) UN Doc A/Res/68/109 < www.uncitral.org/pdf/english/texts/arbitration/rules-ontransparency/Rules-on-Transparency-E.pdf $>$ (UNCITRAL Transparency Rules).

185 See Schill (n 188) 369. 186 UNCITRAL Transparency Rules (n 184), art 1(1).

187 ibid, art 2. $\quad 188$ ibid, art 3. $\quad 189$ ibid, art 1(1). 190 ibid, art 7(2) and 7(5).

191 See Biwater (n 180) para 121. 192 UNCITRAL Transparency Rules (n 184) art 1(9).

193 United Nations Convention on Transparency in Treaty-based Investor-State Arbitration (adopted 10 December 2014, opened for signature 17 March 2015, not yet in force) <www. uncitral.org/pdf/english/texts/arbitration/transparency-convention/Transparency-Convention-e. pdf $>$ (Mauritius Convention).

194 See UNCITRAL Transparency Rules (n 184) art 1(2) and Mauritius Convention (n 193) art 1(1).

195 Mauritius Convention (n 193) art 2(1). 196 ibid, art 2(2).

197 UNCITRAL Transparency Rules (n 184) art 8. 
in IIL. 198 Information about investment disputes that was previously confidential will be readily accessible to host State populations. By enabling host State populations to understand the details of investment arbitration that affect the State, they can evaluate the conduct of government officials and consider the strength of the government's defence of the claim. ${ }^{199}$ Should it be necessary, they can hold the government to account through their constitutional and political processes. ${ }^{200}$ However a host State population responds to investment disputes, they can create a mandate based on the factual situation existing in the host State. The ability of a host State population to do this forms a fundamental aspect of the right to economic self-determination. Therefore, this form of transparency supports the creation of an alternative understanding of sovereignty in IIL.

A second trend has been the development of a transparency policy in relation to the negotiation of IIAs, which is most notable in relation to the Transatlantic Trade and Investment Partnership (TTIP). The TTIP is a proposed trade agreement between the European Union (EU) and the United States of America (USA) that also seeks to open the market for investment and services. ${ }^{201}$ Although the EU is not a State, and as such economic selfdetermination is not directly applicable, the notions of accountability and good governance embodied by this right are transferable to the EU, which has the mandate to enter into IIAs on behalf of its Member States.

The creation of the TTIP has become controversial following the involvement of civil society groups who are opposed to its terms. These groups have been able to gain information about the proposed agreement as a result of increasing transparency and have the potential to influence the economic policies that the TTIP seeks to achieve through actions that are analogous to the exercise of the right to economic self-determination. This development supports the adoption of an alternative understanding of sovereignty.

The initial discussions regarding the TTIP involved low levels of transparency. In July 2014, the European Ombudsman, acting on her own initiative, launched an inquiry into the lack of transparency in relation to the TTIP. ${ }^{202}$ This resulted in several changes. In October 2014, the TTIP negotiating mandate was published for the first time. ${ }^{203}$ By November 2014,

198 See Schill (n 175); Calamita (n 175).

199 Ortino (n 177) 134; Hofmann and Tams (n 175) 201-2.

200 Hofmann and Tams (n 175) 201-2; Schill (n 175) 364.

201 See European Commission, "What is TTIP about? (1 April 2015) <http://ec.europa.eu/trade/ policy/in-focus/ttip/about-ttip/>.

202 See European Ombudsman, 'Transparency and public participation in relation to the Transatlantic Trade and Investment Partnership ("TTIP") negotiations" <http://www. ombudsman.europa.eu/en/cases/caseopened.faces/en/54631/html.bookmark>.

203 See European Commission, News Archive, 'TTIP: 'I'm delighted that EU governments decided to make the TTIP negotiating mandate public' - says EU Trade Commissioner De Gucht' (9 October 2014) <http://trade.ec.europa.eu/doclib/press/index.cfm?id=1162> and Council 
both the new president of the EU Commission, Jean-Claude Juncker, and the newly appointed European Commissioner for Trade, Cecilia Malström emphasized the need for a 'fresh start' with regard to the transparency of the TTIP. ${ }^{204}$ The 'fresh start' included the disclosure of negotiating texts and TTIP documents being shared between the Commission, European Parliament and Council. ${ }^{205}$ This enabled the negotiating aims of the parties to the TTIP to be scrutinized, both within the EU and more widely by the populations of the Member States that would be affected by the agreement. However, only EU documents are being released. The Commission's position is that it would need explicit agreement of the USA for the release of documents that the USA has generated. ${ }^{206}$ Despite this significant limitation, the Commission continued to release EU documentation on the TTIP. Following the European Ombudsman's decision, ${ }^{207}$ on 7 January 2015, the EU published proposed legal texts in areas governed by the TTIP, new position papers, factsheets and a 'Reader's Guide'. ${ }^{208}$ The European Ombudsman welcomed this move, but she recommended that further steps be taken to improve transparency and stated that USA resistance was not sufficient to deny EU citizens transparency. ${ }^{209}$ The actions of the European Ombudsman generated sufficient pressure to enable the release of key documents regarding the TTIP. This provided civil society groups with enough information to raise concerns regarding the potential implications of the TTIP.

The impact of increased transparency became evident on 13 January 2015 when the findings of a public consultation on investment protection and ISDS

of the European Union, 'Directives for the negotiation on the Transatlantic Trade and Investment Partnership between the European Union and the United States of America' (9 October 2014) $<$ http://data.consilium.europa.eu/doc/document/ST-11103-2013-DCL-1/en/pdf $>$.

${ }_{204}$ See European Commission, News Archive, 'Commission to further boost TTIP transparency' (19 November 2014) <http://rade.ec.europa.eu/doclib/press/index.cfm?id=1201> and European Commission, 'How we'll make TTIP happen' (20 March 2015) <http:/ec.europa.eu/trade/policy/ in-focus/ttip/about-ttip/process/\#_transparency>.

${ }^{205}$ See European Commission, News Archive, 'Opening the windows: Commission commits to enhanced transparency in TTIP' (25 November 2014) < http://trade.ec.europa.eu/doclib/press/index. $\mathrm{cfm}$ ?id=1205\&title=Opening-the-windows-Commission-commits-to-enhanced-transparency-inTTIP>.

${ }^{206}$ See European Commission, 'Communication to the Commission concerning transparency in TTIP negotiations' (25 November 2014) <http://ec.europa.eu/news/2014/docs/c_2014_9052_en. pdfs.

${ }^{207}$ See European Ombudsman, 'Decision of the European Ombudsman closing her owninitiative inquiry OI/10/2014/RA concerning the European Commission' <www.ombudsman. europa.eu/en/cases/decision.faces/en/58668/html.bookmark>.

${ }^{208}$ See European Commission, News Archive, 'European Commission publishes TTIP legal texts as part of transparency initiative' (7 January 2015) <http://rade.ec.europa.eu/doclib/ press/index.cfm?id=1231\&title=European-Commission-publishes-TTIP-legal-texts-as-part-oftransparency-initiative>.

${ }^{209}$ See European Ombudsman, Press Release No 1/2015, 'Ombudsman: "Further steps to increase TTIP transparency necessary"' (7 January 2015) <http://www.ombudsman.europa.eu/en/ press/release.faces/en/58669/html.bookmark $>$. 
in TTIP were published. ${ }^{210}$ Many of the responses were from civil society groups that did not support the TTIP and utilized a pro forma response to the consultation that was intended to demonstrate how unpopular the TTIP was in certain sections of society. ${ }^{211}$ In response to the outcome of the public consultation, Malström recognized the need to consult with civil society. ${ }^{212}$ Whilst proceeding with the TTIP, the Commission is more cognizant of the need to ensure that they have the support of key sectors within host State populations. The reaction of civil society groups to the TTIP is analogous to the exercise of their right to economic self-determination. As part of a population affected by an economic decision, civil society groups have made a choice regarding their preferred economic policy using their freedom of expression, which forms a fundamental aspect of democratic participation. ${ }^{213}$ By taking into account the objections to the TTIP from civil society groups, the Commission is, in effect, responding to the exercise of this 'right'.

The progress made by the Commission, albeit not always of its own volition, evidences the growing demand for transparency in relation to economic policies. The Commission has responded to calls for transparency to provide the negotiation procedure with accountability and credibility in the public eye. $^{214}$ The need for credibility reflects that the Commission requires a mandate from the populations of its Member States. Yet, through the provision of this information, the Commission has been made aware that its proposals in the TTIP do not have the full support of many sectors of the TTIP's potential host State populations. The reaction of civil society groups to the TTIP is only as a result of the increased transparency of the negotiations. The TTIP evidences how transparency supports an alternative understanding of sovereignty in IIL based on how members of civil society groups acted in a manner analogous to exercising the right to economic selfdetermination. The approach adopted by civil society groups in response to the TTIP is capable of functioning on a larger scale within the traditional framework of the right to self-determination. With increased transparency, all interested sectors of the host State population would be able to contribute to the discussion of their State's economic policy, enabling them to exercise their right

210 European Commission, Press Release, 'Report Presented Today: Consultation on Investment Protection in EU-US trade talks' (13 January 2015) < http://trade.ec.europa.eu/doclib/press/index. cfm?id=1234> (Consultation Press Release).

211 The Commission received nearly 150,000 responses to the public consultation. Approximately 97 per cent of these responses were submitted through 'on-line platforms containing pre-defined answers'. European Commission, Fact Sheet, 'Report on the online consultation on investment protection and investor-to-State dispute settlement in the Transatlantic Trade and Investment Partnership Agreement' (13 January 2015) < http://europa.eu/rapid/pressrelease_MEMO-15-3202_en.htm?locale=en>.

212 Consultation Press Release (n 210).

213 K Boyle and S Shah 'Thought, Expression, Association, and Assembly' in D Moeckli, S Shah and S Sivakumaran (eds), International Human Rights Law (2nd edn, OUP 2014) 218.

214 Schill (n 175) 367. 
to economic self-determination. This supports the adoption of an alternative view of sovereignty in IIL.

The development of recent transparency initiatives, both in relation to informing host State populations regarding any existing disputes, and the negotiation of further IIAs, evidence that civil society is seeking to engage with economic policy and highlights the need for States and regional organizations to provide access to these materials so that host State populations can be fully informed. This political momentum can provide the impetus for altering the understanding of sovereignty in IIL. As transparency assists host State populations to exercise their right to economic self-determination, ${ }^{215}$ it is only appropriate that the understanding of sovereignty in IIL enables its full exercise.

\section{IMPLICATIONS OF THE ADOPTION OF AN ALTERNATIVE VIEW OF SOVEREIGNTY IN} INTERNATIONAL INVESTMENT LAW

An alternative view of sovereignty in IIL facilitates a broader understanding of sovereignty, and given the trend towards transparency in IIL, can challenge the mainstream narrative as the dominant perspective in IIL. Should the proposed notion of sovereignty be adopted, this is likely to affect how IIL functions both in terms of the formulation of IIAs and ISDS. However, it is submitted that the acceptance of this approach will not require radical changes to the IIL regime.

New generation IIAs evolve in response to investment tribunal awards and to reflect the broader impacts of FDI. The proposed understanding of sovereignty creates a mandate for the host State to initiate reforms to IIAs that reflect the will of the host State population. When host States negotiate IIAs with this mandate, it is anticipated that they would be more creative in aligning investment protection standards with the protection of policy and regulatory space. ${ }^{216}$ For example, in several investment awards host States have formulated their arguments based on their sovereign right to regulate environmental law. ${ }^{217}$ Several IIAs now contain exemptions for environmental laws and labour standards. ${ }^{218}$ Adopting the proposed view of sovereignty in IIL could lead to changes to the terms of IIAs such as the inclusion of further provisions protecting human rights, labour and environmental standards. In contrast, new terms may mirror the desired economic policies of the host State. Therefore, the alternative narrative suggested is not a reworking of IIL, but

215 ibid 364, 369; Calamita (n 175) 650.

216 As to how this could be achieved, see Spears ( $\mathrm{n} 75$ ); Z Huaqun, 'Balance, Sustainable Development, and Integration: Innovative Path for BIT Practice' (2014) 17 JIEL 299; B Condon, 'Treaty Structure and Public Interest Regulation in International Economic Law' (2014) 17 JIEL 333.

217 See for example, Compañia del Desarrollo de Santa Elena, S.A. v the Republic of Costa Rica ICSID Case No ARB/96/1 Award, 17 February 2000; SAUR International S.A. v Argentine Republic ICSID Case No ARB/04/4, Decision on Jurisdiction and Liability, 6 June 2012.

218 For example, 2004 Canadian Model FIPA, arts 10 and 11; 2012 US Model BIT, arts 12 and 13. 
rather, it emphasizes reforms that are currently being pursued within the IIL regime that seek to promote and protect the host State's right to regulate ${ }^{219}$ as part of IIL's continuing evolution.

Existing IIAs could be interpreted in the light of State practice between treaty parties. $^{220}$ The Vienna Convention on the Law of Treaties ${ }^{221}$ enables a treaty interpreter to take into account subsequent State practice as part of the primary stage of treaty interpretation. ${ }^{222}$ This approach was taken when the Free Trade Commission of NAFTA issued a joint interpretative statement to limit the scope of the 'fair and equitable treatment' and 'full protection and security' standards in Article 1105 of NAFTA. ${ }^{223}$ By doing so, the State parties to NAFTA limited the impact that Article 1105 NAFTA would have on their sovereign powers. Consequently, States could use subsequent practice as a means to ensure that existing IIAs are construed in a manner consistent with the mandate conferred upon them by their population when they exercise the right to economic self-determination.

In whatever form new or amended IIAs take, it is likely that there will be greater public acceptance of their terms given the direct mandate from the host State population. Consequently, the strong reaction to the provisions of the TTIP would be less likely to occur. There is also likely to be a decreased risk of conflict between FDI projects and minority and indigenous populations when their perspectives are reflected in the mandate of the State. ${ }^{224}$ The proposed understanding of sovereignty could increase the sensitivity of foreign investors to the potential impacts of their investment projects, thereby reducing disputes over regulatory measures that may negatively impact the profitability of those projects. The methodological difficulties of addressing the intersection between IIL and, for example, human rights obligations, ${ }^{225}$ could, to a certain degree, be averted with this approach.

Even with well-drafted IIAs, disputes regarding FDI will arise. Investment tribunals are then required to interpret IIAs to reach a resolution. If investment tribunals are willing to privilege State practice over normative

219 F Ortino, 'Refining the Content and Role of Investment "Rules" and "Standards": A New Approach to International Investment Treaty Making' (2013) 28 ICSID Review - Foreign Investment Law Journal 152.

220 A Roberts, 'Power and Persuasion in Investment Treaty Interpretation: The Dual Role of States’ (2010) 104 AJIL 179.

221 Vienna Convention on the Law of Treaties (adopted 23 May 1969, entered into force 27 January 1980) 1155 UNTS 331.

222 ibid, art 31(3)(a).

223 Notes of Interpretation of Certain Chapter 11 Provisions (NAFTA Free Trade Commission, 31 July 2001) available at US Department of State <www.state.gov/documents/organization/ 38790.pdf $>$.

224 On the requirement to consult with indigenous peoples, see F Lenzerini, 'Investment Projects Affecting Indigenous Heritage' in V Vadi and B de Witte (eds), Culture and International Economic Law (Routledge 2015) 72.

225 See E Guntrip, 'International Human Rights Law, Investment Arbitration and Proportionality Analysis: Panacea or Pandora's Box' (EJIL: Talk! 7 January 2014) <www.ejiltalk.org/internationalhuman-rights-law-investment-arbitration-and-proportionality-analysis-panacea-or-pandoras-box/>. 
considerations when addressing sovereignty, host States can legitimately refer to their sovereign right to regulate in a manner that would be accepted by an investment tribunal. For example, actions taken in response to economic and constitutional crises, such as the Argentinian economic collapse of 2001-02, would be considered to be sovereign acts that are not automatically limited by reference to the terms of IIAs. This enables host States to manage their domestic jurisdiction with more freedom than IIAs currently permit. Investment tribunals regularly consider the sovereign power of the host State in investment awards. Therefore, current practice would not change. However, given the lack of defences available to host States in IIL, increasing an investment tribunal's ability to consider the purpose of the host State's sovereign acts involves a more substantial adjustment to ISDS. Nonetheless, this could reduce the controversy surrounding IIL by conferring the regime with increased legitimacy from the perspective of host State populations. Further, it might reduce the dissatisfaction of some host States with the outcomes of ISDS and the IIL regime more generally. ${ }^{226}$

It is recognized that the creation of IIAs and the interpretation of investment protection standards in the manner described will generate innovative provisions in IIAs and new legal understandings of the term 'sovereignty'. This outcome is not problematic. Koskenniemi recognizes that legal norms are not automatically linked to restricting sovereignty. ${ }^{227}$ Therefore, host States would still be able to fully exercise their sovereign powers. Further, the new legal principles generated will merely act as reference points for future legal argumentation, permitting mainstream and alternative views of sovereignty to develop. As international law is not fixed, arguments will advance, and if necessary, the mainstream view can alter its position accordingly.

The acceptance of the proposed view of sovereignty will affect the balance of IIL. By expressing a minority view in IIL, this narrative has the potential to alter the terms of new IIAs to favour host State interests and may give more leeway for interpretations of investment protection standards that respect State sovereignty. Nevertheless, this would not require radical changes to the IIL regime. Rather, it would result in the evolution of the regime, giving rise to more nuanced decision-making and a new form of normativity in IIL that would be subject to further legal argumentation. Therefore, the adoption of a new perspective on sovereignty in IIL allows the regime to reflect the interests of those States most affected by it.

\section{CONCLUSION}

This article has presented a minority view of how sovereignty can operate in IIL based on a new political perspective. By relying on the right to economic

226 Since 2007, Bolivia, Ecuador and Venezuela have denounced the ICSID Convention (n 181).
227 Koskenniemi (n 6) 234. 
self-determination, this view of sovereignty enables host State populations to create a mandate that reflects the factual and political elements of the IIL regime. Given this, the article has sought to emphasize the narrow, normative conception of sovereignty that is currently applied within IIL. By expanding the concept of sovereignty in IIL to take into account factual considerations, the regime can be accorded greater credibility. Host States will be able to regulate more freely and critiques of IIL that focus on the restrictions placed on host State sovereignty will become less prevalent. This outcome will only occur if IIL is able to expand its limited ethos. This will not be an easy task due to the movement of power away from the State towards decision-makers in IIL as a result of the fragmentation of public international law. There is potential for fundamental reform if the proposed understanding of sovereignty were to be adopted as the mainstream view. The current political climate encouraging transparency in IIL supports such a move, but the power to make changes remains with the decision-makers and depends on whether their political choices are sufficiently influenced by these developments. If decision-makers fail to address the current critiques of IIL, and continue to limit host State sovereign power by adopting the mainstream position, IIL runs the risk of ostracizing host States. To prevent this from happening, some latitude must be given for host States to act in the best interests of their populations. The framework presented in this article provides one possible avenue to address this concern. 